\title{
1 Frost Boils and Soil Ice Content: Field Observations
}

2

3 P. P. Overduin, Potsdam Institute for Climate Impact Research, Telegrafenberg C4,

414473 Potsdam, Germany. Tel: +49-331-288-2534. Fax: +49-331-288-2137. Email:

5 fsppo@uaf.edu.

6

7 Dr. Douglas L. Kane, Water and Environmental Research Center, University of Alaska

8 Fairbanks, P. O. Box 755860, Fairbanks, AK, USA. Email: ffdlk@uaf.edu. 


\section{$9 \quad$ Ice content and frost boils: Field observations}

10 Overduin, P. P., Kane, D. L.

\section{Abstract}

13 Our aim is to measure and explain the seasonal changes in soil ice content in the frost

14 boils of Galbraith Lake, Alaska. Instruments were installed in a frost boil to monitor the 15 ground surface position and soil state over a period of four years. By comparing the

16 subsidence and thaw rates, we calculate the soil ice content as a function of depth.

17 Measured soil temperatures, liquid water contents and bulk apparent thermal

18 conductivities are used to estimate latent heat production and release in the soil. The

19 frost boils heave during freezing and settle during thaw while the surrounding tundra

20 heaves negligibly, but subsides measurably. Despite large changes in freezing rates

21 from year to year, total heave and its distribution across the frost boil are similar

22 between years. Winter air temperature and snow depth influence the freezing rate and

23 ice distribution as a function of depth, but not the overall heave. This suggests that

24 heave is controlled by water availability rather than the rate of heat removal from the

25 soil. Areal ground subsidence rates between 2 and $5 \mathrm{~cm} / \mathrm{yr}$ are due to the disappearance

26 of ice at the base of the active layer, raising the possibility of ongoing thermokarst

27 expansion around Galbraith Lake.

29 Keywords: permafrost, patterned ground, segregated ice, soil thermal properties, frost

30 boil, non-sorted circle, freezing and thawing, climate variability, heave, subsidence 


\section{Introduction}

32 The formation of ice in soil lies at the heart of many processes unique to permafrost regions, including differential heave, the formation of patterned ground and solifluction

34 (Washburn 1956). This study is directed at frost boils located at Galbraith Lake, in the

35 Brooks Range of Alaska. Walker et al. (2004) mentioned numerous mechanisms at

36 work in the creation of the frost boils they studied in Alaska and Canada, including frost cracking, heave, mass displacement and sorting. Vliet-Lanoë (1991) reviewed the plausible mechanisms of formation of frost-boils. Of the 19 mechanisms originally proposed for patterned ground formation by Washburn (1956), two mechanisms emerged as the most likely: convection-cell like cryoturbation and load casting. Based on the observed soil horizon morphology at Galbraith Lake, Ping et al. (2003) suggested that their genesis was probably linked to a single extrusion of lower soil horizons through structural weaknesses in the overlying horizons, for example through frost cracks. This is consistent with the lack of organic material in lower horizons at the frost boil boundaries, which would have indicated the convection-cell like movement proposed elsewhere (MacKay 1979). The frost boil center, on the other hand, is free of vegetation, but one may find roots that have been exposed at the surface and stretched by soil movement. Both facts suggest that radially outward spreading of the exposed mineral material is actively occurring. The role of differential frost heave as a result of

50 segregated ice formation in creating and maintaining these features is unclear and what 51 additional processes are involved is also unclear (Vliet-Lanoë 1991).

52 Measuring changes in soil ice content is not trivial, even by destructive sampling methods. It is further complicated by the fact that ice segregation during freezing of the active layer and upper permafrost can lead to highly variable spatial concentrations of 
55 ice at a variety of scales. Methods that have been used for ice content include:

56 gravimetric; radar, either as ground-based or remote techniques; acoustics; neutron

57 absorption for the determination of total water content; dielectric methods (Bittelli et al.

58 2003) and volumetric methods. We use the changes in soil volume, temperature and

59 thermal properties during freezing and thawing to draw conclusions about changes in

60 ice volume. Our objectives are to describe the heave dynamics of a frost-boil, to

61 quantify the role of seasonal ice growth in these features and to evaluate the role of ice

62 formation and segregation in differential frost heave at this site.

63

\section{Methods}

65 Site

66 Galbraith Lake is about $3 \mathrm{~km}$ long. It is located at the west end of Atigun Gorge on the 67 north side of the Brooks Range, Alaska (68²8.890’N, $\left.149^{\circ} 28.744^{\prime} \mathrm{W}\right)$. Water enters the

68 lake through a tributary at its northern end and through an alluvial fan that forms its

69 western shore. It drains into the Saganivirktok River, which flows across the North

70 Slope of Alaska into the Arctic Ocean. Aerial photographs show evidence of a series of

71 old shorelines beyond the northern end of the lake. Within this region of exposed and

72 reworked lake bed, a mixture of lacustrine and fluvial sediments form a nearly

73 horizontal plain between outwash fans of streams into the valley from the west, and

74 bluffs on the east. At present, there is an airstrip located on the west side of the plain,

75 and the Dalton highway and the Trans-Alaska Pipeline run north to south along the east

76 side of the valley. The site is poorly drained and the water table is within $20 \mathrm{~cm}$ of the

77 ground surface during the growing season. Land-cover type is classified as moist non-

78 acidic tundra, the soil pedon is classified as a cryaquept and the soil horizons are 
contorted by cryoturbation (Ping et al. 2003). From 1987 until 2001, mean annual

80 ground temperature ranged between -8 and $-4{ }^{\circ} \mathrm{C}$ at the permafrost table and between -

815.7 and $-4.7^{\circ} \mathrm{C}$ at $20 \mathrm{~m}$ (Osterkamp 2003).

82 Visual and near infrared band images of the site were collected using the Bi-camera

83 Observation Blimp (BOB) low-altitude aerial photography system (Harris and

84 Helfferich 2005). Ground features were used to georectify the images, which have a

85 resolution of better than $0.07 \mathrm{~m}$. The site is shown (Figure 1) in a normalized difference

86 image (NDVI) of the reflected near infrared and red bands. NDVI is an index for

87 reflection from photosynthesizing vegetation. It is used here to identify vegetation-free

88 patches of ground, which appear black. The only features devoid of vegetation in the

89 field of view are the frost boils, water surfaces and some humans, which appear darker

90 than the vegetated surfaces (Figure 1).

\section{$91 \quad$ Frost boil morphology}

92 Frost boils at Galbraith Lake are identified at the ground surface as roughly circular

93 areas free of vegetation and between 0.5 and $1.5 \mathrm{~m}$ in diameter. In some cases, several

94 frost boils appear to have developed close enough to one another to form linear regions

95 of frost boil up to $3 \mathrm{~m}$ long. The vegetation cover of the surrounding tundra is complete,

96 and the frost boils thus have well-defined boundaries (Figure 1, inset). Based on the 110

97 frost boils identified in Figure 1 (C), the mean distance between frost boils is $5.6 \pm 0.6$

$98 \mathrm{~m}$. They are not uniformly distributed, as the terrain is also the site of other periglacial

99 features, including ice-cored mounds (A), thermokarst ponds (B) and ice wedges (D),

100 that are found throughout the image. Dark spots within the oval (E) are people. Frost

101 boils are also found in the surrounding tundra, outside of the old lake bed region, but 
102 tend to be covered with vegetation to some degree, and are smaller with less distinct 103 boundaries.

104 Galbraith Lake frost boils appear to have undergone sorting, with fine silty-clay mineral

105 material in the frost boil center and sandy soil underlying the vegetated margins and

106 surrounding tundra of the boils. The surfaces of the frost boils are cracked in a columnar

107 structure, and a crust has developed. Major ion analyses of a crust sample showed little

108 difference between the crust and the soil beneath it (Ping et al. 2003). They are slightly

109 domed, and their elevation relative to the surrounding tundra varies with the time of

110 year, which is examined in the section on frost heave, below.

111 A soil pit roughly bisecting a frost boil was carefully excavated on August 25, 2001.

112 The soil pit was approximately $1.4 \mathrm{~m}$ wide at the ground surface. Soil was removed by

113 horizon with consideration for the three-dimensional structure of the horizons, and

114 replaced and compacted so that the pit was refilled. Beneath the center of the frost boil

115 there is little change in soil composition with depth. All sampled horizons were mineral

116 with organic contents of less than 3\% by weight, had bulk densities in the range of 1.62

117 to $1.76 \mathrm{~g} \mathrm{~cm}^{-3}$ and saturated soil-paste pHs of 8 to 8.2 (Table 1). Little difference was

118 observed in soil texture variation with depth, down to $0.73 \mathrm{~m}$. Soils surrounding the

119 frost boil have organic upper horizons 0.05 to $0.20 \mathrm{~m}$ thick with lower bulk density,

120 higher carbon content, and support a 100\% cover of mosses and sedges. The soil pit was

121 excavated to a depth of $1.3 \mathrm{~m}$ and the frost table beneath the center of the frost boil was

122 encountered at $0.73 \mathrm{~m}$. A jackhammer was used to excavate below the frost table. The

123 thaw depth in the frost boil exceeded the thaw depth immediately adjacent to and at a

124 distance of $2.5 \mathrm{~m}$ from the boil by over $0.22 \mathrm{~m}$, creating a bowl-shaped depression in

125 the frost table beneath the frost boil. Many ice lenses were encountered between 0.75 to 
$1260.83 \mathrm{~m}$, running parallel to the frost table and containing ice lenses up to $7 \mathrm{~mm}$ thick.

127 They were angled upwards towards the margin of the frost boil and not found beneath

128 the adjacent tundra. Below $0.83 \mathrm{~m}$, ice layers with a blocky, horizontally-oriented

129 structure and 0.02 to 0.05 m thickness were separated by thinner soil layers. This ice

130 was associated with the transition zone, the layer of soil that is usually permafrost, but is

131 subject to infrequent thaw during warm years. A core was drilled into the bottom of the

132 soil pit to determine the lower extent of the ice-rich deposits: ice layers were

133 encountered down to te termination depth of $1.6 \mathrm{~m}$. Thus, the frost boil was thawed to a

134 depth of $0.73 \mathrm{~m}$, with thin ice lens for $0.10 \mathrm{~m}$ below the frost table, and thicker ice

135 layers underlying these lenses for at least another $0.77 \mathrm{~m}$. The estimated volumetric ice

136 content of the soil below $0.83 \mathrm{~m}$ was over $0.90 \mathrm{~m}^{3}$ per cubic meter of soil.

137 The frost boil morphology and material grain-size results in a classification after Zoltai

138 and Tarnocai (1981) as raised-center mudboil, despite the poor drainage of the site.

139 Ping et al. (2003) concluded that the soil profile morphology showed upward extrusion

140 of clayey material from a lower soil horizon into an overlying sandy horizon, locally

141 displacing the upper horizon and creating a textural differentiation at the ground

142 surface.

143 Instruments

144 Temperature, volumetric liquid water content and thermal conductivity sensors were

145 installed in the soil pit wall between the surface of the soil and $1.36 \mathrm{~m}$ depth (Figure 2).

146 Temperatures were measured hourly using a vertical array of thermistors. The

147 thermistors were calibrated using a de-ionized water-ice mixture, from which a

148 thermistor-specific offset, $\delta_{0}$, for the Steinhardt-Hart equation was generated:

$149 \quad T^{-1}=1.28 \times 10^{-3}+2.37 \times 10^{-4}\left(\ln \left(R_{T}-\delta R_{0}\right)\right)+9.06 \times 10^{-8}\left(\ln \left(R_{T}-\delta R_{0}\right)\right)^{3}$ 
150 where $R_{T}$ is the measured resistance and $\delta R_{0}$ is the resistance offset at $0{ }^{\circ} \mathrm{C}$. The

151 temperature sensor uncertainty is better than $\pm 0.01^{\circ} \mathrm{C}$ at $0{ }^{\circ} \mathrm{C}$.

152 Time domain reflectometry sensors (Campbell Scientific CS605) connected to a

153 reflectometer and datalogger (Campbell Scientific TDR100 and CR10X) were used to

154 record the apparent sensor length at one-hour intervals, which is related to soil moisture

155 content. In addition, the entire reflected waveforms for each sensor were measured once

156 per week to verify the TDR100 waveform analysis algorithm, and to provide an

157 alternate time series. Occasional TDR100 waveform analysis algorithm failure occurred

158 as a result of temperature-induced changes in the sensor cable length. This problem was

159 solved by trial and error determination of two cable lengths in the datalogger program,

160 one for thawed soil and one for frozen soils. The sensors had been previously calibrated

161 in the laboratory using water and air as reference materials following the method of

162 Heimovaara et al. (1995). The bulk relative dielectric permittivity data was used to

163 calculate liquid water content using Roth et al.'s (1990) mixing model for mineral

164 horizons and an empirical relationship for organic horizons similar to the ones under

165 study (Overduin et al. 2005). The accuracy of the method is estimated to be better than

$1660.05 \mathrm{~m}^{3} \mathrm{~m}^{-3}$ (Heimovaara et al. 1995).

167 Thermal diffusivity is calculated as the ratio of thermal conductivity and heat capacity:

$168 \quad D=\frac{k}{\rho C}$

169 where $D, k, \rho$ and $C$ are the bulk thermal diffusivity, conductivity, density and

170 volumetric heat capacities of the soil, respectively. Thermal conductivity was measured

171 using Hukseflux TP01 transient heat pulse sensor installed at 0.1 and $0.2 \mathrm{~m}$ depth

172 beneath the center of the frost boil. The radial temperature difference following heating 
173 for $180 \mathrm{~s}$ was measured and analyzed following Overduin et al. (2006). All data points

174 were included in the analysis, including peaks in bulk apparent thermal conductivity due

175 to changes in phase induced by the transient heat pulse. The uncertainty in $k$ is

176 estimated to be $\pm 0.01 \mathrm{~W} \mathrm{~m}^{-1} \mathrm{~K}^{-1}$ over the range of 0.3 to $4.0 \mathrm{~W} \mathrm{~m}^{-1} \mathrm{~K}^{-1}$ (Overduin et al.

177 2006).

\section{Thaw and frost penetration depth}

179 We used the decrease in liquid water content at each TDR sensor to identify the time at

180 which the freezing front passed each sensor. Phase change was identified as the point of

181 inflection in the time series of soil liquid water content. To interpolate thaw and frost

182 front positions between sensor depths, the data were fit to a simplified solution of the

183 Stefan problem:

184

$z=A \sqrt{\sum\left|\bar{T}-T_{f}\right|}+B$

185 where the sum indicates summation over days of the year, $\bar{T}$ is the mean daily air

186 temperature, $T_{f}$ is the freezing point and $A$ and $B$ are constants. The term within the

187 square root is referred to as the degree-days of freezing or thawing (Yershov 1990). The

188 coefficients $A$ and $B$ are specific to a freeze or thaw season, and were used to predict

189 thaw based on cumulative degree-days of thawing.

190 Frost heave

191 By comparing soil volumes in the thawed and frozen states, changes in the volumetric

192 fractions of water and ice may be inferred. Heave was measured in two ways. For the

193 excavated site, fiberglass rods $1.22 \mathrm{~m}$ long and $3 \mathrm{~mm}$ in diameter were anchored in the

194 permafrost at depths between 0.7 and $1 \mathrm{~m}$ using $5 \mathrm{~cm}$ long cross-pieces fastened using

195 screws. The vertical rods extended above the ground surface. The rods were distributed

196 in a line from the approximate center of the frost boil to a point $2.47 \mathrm{~m}$ away (Figure 2). 
197 Metal washers were free to slide along the rods and rested on the ground surface. The

198 rod length exposed above the metal washer was measured at irregular intervals

199 throughout the year. At a second frost boil a few meters from the first, five ultrasonic

200 distance sensors (Sonic Ranger SR50, Campbell Scientific Corporation) were mounted

201 on a horizontal rod supported by two vertical members, which were anchored in the

202 permafrost at a depth of over $1.5 \mathrm{~m}$ and encased in tubing that extended over the active

203 layer depth. The sensors have a resolution of $0.1 \mathrm{~mm}$ and an accuracy of $+/-0.01 \mathrm{~m}$, after

204 correction for variations in air temperature. The sensors record the signal from the

205 nearest target in their approximately $22^{\circ}$ field of view. They are thus affected by the

206 presence of snow and vegetation. The hourly values used here are smoothed using a

207 running average during snow-free periods only.

208 Following suggestions by Burn (1998), we define the active layer depth as the

209 penetration depth of the $0{ }^{\circ} \mathrm{C}$ isotherm. To calculate the rate of thawing in spring, the

210 position of the $0{ }^{\circ} \mathrm{C}$ isotherm from 0.12 to $1.36 \mathrm{~m}$ was interpolated as described in the

211 previous section. We assume that daily subsidence at the surface is due to daily ice

212 melting at the thaw front. Although uncertainty in settling rates at a daily time scale is

213 high and probably depends on flow-rates of excess moisture from the thawing front: the

214 correspondence between the rates of subsidence and thaw suggests that our assumption

215 is reasonable. Measurable subsidence did not continue after the active layer reached its

216 maximum depth at the end of summer.

217 We define the vertical positions of the ground surface $z_{0}(t)$, and the phase change

218 boundary, $z_{f t}(t)$, relative to the ground surface at the start of thawing or freezing. Settling

219 is ascribed to the melting of ice in the soil to the depth $z_{f t}$. Accounting for the difference 
220 in ice and water densities, the segregated ice content averaged over the entire profile

221 from $z_{0}$ to $z_{f t}$ before thawing is then given by:

$222 \quad \theta_{i}^{\prime \prime}=\frac{\Delta z_{0}}{\Delta z_{f t}}-\theta_{w} \frac{\rho_{w}}{\rho_{i}} \frac{\Delta z_{f t}-\Delta z_{0}}{\Delta z_{f t}}$

223 where $\rho_{i}=917.0 \mathrm{~kg} \mathrm{~m}^{-3}$ and $\rho_{w}=999.8 \mathrm{~kg} \mathrm{~m}^{-3}$ are the densities of water and ice,

224 respectively, and $\Delta z_{0}$ and $\Delta z_{f t}$ are the change in the ground surface and the phase change

225 boundary positions.

226 Volumetric latent heat production

227 Changes in ice content can also be inferred from latent heat production and

228 consumption in the frozen ground (Roth and Boike 2001). Conservation of energy and

229 Fourier's law lead to the heat diffusion equation in one dimension:

$230 \quad \frac{\partial}{\partial t}(\rho C T)=r_{h}+\frac{\partial}{\partial z}\left(k \frac{\partial T}{\partial z}\right)$

231 where $r_{h}$ is the heat production or consumption per unit volume. We use the temperature

232 profile beneath the frost boil center to estimate the heat production or consumption in

233 the soil by integrating over each soil layer between sensors at depths $z_{j}$ and $z_{j+1}$, and

234 between observation time steps $t_{k}$ and $t_{k+1}$, where $j$ and $k$ are ordination subscripts

235 denoting steps in observation time or depth. Integrals are approximated using the

236 trapezoidal rule and the partial derivative of temperature is estimated using a central

237 finite difference. The approach of Roth and Boike (2001) is followed, except that a time

238 dependent $C$ is calculated using equation 6 . The bulk soil heat capacity depends

239 primarily on the soil's volumetric liquid water content and is calculated from measured

240 soil composition. The dependence of the bulk heat capacity on composition is the

241 volumetric fraction-weighted arithmetic mean of the soil components: 
$\rho C=\sum_{n=a, i, w, s} \rho_{n} C_{n} \theta_{n}$

243 where $\rho$ is the soil bulk density, and $\rho_{n}$ is the density, $C_{n}$ the heat capacity, and $\theta_{n}$ the

244 volumetric fraction of soil component $n$. The subscripts refer to air (a), ice (i), water (w)

245 and soil (s). The volumetric heat capacities of ice, water and soil used were 1.93, 4.18,

246 and $1.88 \mathrm{MJ} \mathrm{m}^{-3} \mathrm{~K}^{-1}$, respectively, while that of air was neglected. The volumetric liquid

247 water content was taken from the TDR measurements and the volume fraction of soil

248 was taken from the porosity measurements in Table 1. Ice content was estimated as the

249 difference between measured liquid water content and the soil porosity, which is

250 equivalent to the assuming saturation and that moisture migration does not take place.

251 This coarse assumption contradicts the clearly observed effects of water migration but is

252 only used in the estimation of soil heat capacity. Since the relative dielectric

253 permittivity of ice is low and similar to that of the soil matrix, the liquid water content is

254 only linearly and weakly dependent on ice content. A 10\% change in the ice content

255 results in a volumetric liquid water content change of less than $0.8 \%$ for the entire

256 period of record, well below the estimated uncertainty in water content. The heat

257 capacity is linearly dependent on estimates in soil component fractions. We estimate its

258 uncertainty, $\delta C$ as the sum of the uncertainties in soil fractional heat capacities:

$259 \delta C=\sum_{n=i, w, s} \delta C_{n}$

260 where the uncertainty introduced by the exclusion of air is ignored. For the unfrozen

261 soil, $\delta C$ is equivalent to the sum of the products of the volumetric heat capacities of the

262 soil components and their uncertainties ( $\left.\delta \theta_{i}= \pm 0, \delta \theta_{w}= \pm 0.05, \delta \theta_{s}= \pm 0.05\right)$. At subzero

263 temperatures, however, ice may segregate. Since we do not measure soil ice content

264 directly, our uncertainty for bulk volumetric soil heat capacity in the frozen soil 
265 increases by a factor of almost 10 and reaches values comparable to the heat capacity of

266 bulk frozen saturated soils (1.6 to $2 \mathrm{MJ} \mathrm{m}^{-3} \mathrm{~K}^{-1}$; Yershov 1990), based on uncertainties

267 in soil component volumetric fractions of $\delta \theta_{i}= \pm 1.0, \delta \theta_{w}= \pm 0.05, \delta \theta_{s}= \pm 0.35$, where

268 the latter value is $(1-\eta)$, where $\eta$ is the porosity. However, this uncertainty is reached only if ice segregation results in the complete displacement of liquid water and soil

270 particles from the soil. The freezing characteristic curves obtained by the TDR sensors

271 and thermistors for these soils show that liquid water exists throughout the measurement

272 period so that soil particles cannot have been displaced, at least at the scale of

273 measurement of the TDR sensor.

274 Values of bulk apparent soil thermal conductivity are calculated using the least squares

275 fit of measured thermal conductivity values against soil temperature (for temperatures

276 below $-1.5^{\circ} \mathrm{C}$ ) shown in Figure 3, which includes both cooling and warming data over

277 a three year period. Calculations of latent heat are restricted to times and depths for

278 which the soil temperature is below $-1.5^{\circ} \mathrm{C}$ to avoid the influence of latent heat

279 changes on measured thermal conductivity values. Fuchs et al. (1978) showed

280 theoretically that the effects of phase change on the apparent thermal conductivity are

281 limited to a well-defined temperature range (for example, -0.5 to $0{ }^{\circ} \mathrm{C}$ for a Palouse

282 loam). The lower limit of this temperature dependency is a function primarily of total 283 soil water content.

284

\section{Results and Discussions}

\section{$286 \quad$ Rates of freezing}

287 Soil temperature and volumetric liquid water content for four hydrologic years

288 (2001/02, 2002/03, 2003/04 and 2004/05) show differences between the four winter 
periods (Figure 4). Following, we describe the observed differences in freezing rate between 2002 and the other years in a variety of ways. During 2001, 2003 and 2004 the active layer rapidly changed from positive temperatures to values less than $-0.1^{\circ} \mathrm{C}$ throughout the soil profile. In these three years the lowering of the zero curtain (i.e. the time taken to bring the entire soil profile to temperatures less than or equal to $-0.1{ }^{\circ} \mathrm{C}$ )

294 from the shallowest sensor at $0.12 \mathrm{~m}$ depth took less than a week (September 19-21, 295 2001, September 9-11, 2003 and September 12-15, 2004). Between 0.12 and 0.77 m, the mean freezing rates (calculated using the position of the $0{ }^{\circ} \mathrm{C}$ isotherm) were $4.8 \mathrm{x}$ $10^{-1}, 1.3 \times 10^{-2}, 3.5 \times 10^{-1}$ and $3.1 \times 10^{-1} \mathrm{~m} \mathrm{~d}^{-1}$ in 2001, 2002, 2003 and 2004, respectively. Although the freezing rate was more rapid in 2001 than in 2003 or 2004, it 299 occurred ten days earlier than in 2003. The freezing rate during the fall of 2002 was more than an order of magnitude lower than in the preceding and following years and the active layer at $0.77 \mathrm{~m}$ depth remained unfrozen until after November 20. Even if the $-0.5^{\circ} \mathrm{C}$ isotherm is used to indicate freezing, freezing was delayed by over a month in at this depth in 2002, compared to other years.

304 We attribute the delay in freezing to changes in snow cover and winter air temperatures.

305 On Oct 1, 2002, over $0.16 \mathrm{~m}$ of snow accumulated. As a result of subsequent snowfalls, 306 the snow pack grew to almost $0.5 \mathrm{~m}$ thickness without diminishing over the course of 307 the winter. During the following winter, snow fell between Sep 6 and Sep 26, 2003, but 308 had disappeared from the frost boil surface by October 1, 2003. Subsequent snow 309 covers that exceeded $0.02 \mathrm{~m}$ lasted for less than 20 days. The effect of snow cover on 310 soil temperatures is not straightforward. Sokratov et al. (2001) used a 30-year data set to 311 show that the ratio between mean air temperatures and soil temperatures at $0.2 \mathrm{~m}$ depth 312 are not correlated with snow depth except during February and March. Taras et al. 
313 (2002) distinguished snow depths sufficient to decouple air and soil temperatures from

314 one another $(>80 \mathrm{~cm})$ from shallow snow depths $(<25 \mathrm{~cm})$ in which air and soil

315 temperatures are highly coupled. Intermediate snow depths were strongly coupled. They

316 found that a $15 \mathrm{~cm}$ increase in snow depth produced a 0.5 to $3.0^{\circ} \mathrm{C}$ increase in soil

317 temperature at the snow-soil interface. Under this scheme, the snow depths observed in

318 2002/03 and 2003/04 correspond to intermediate and shallow snow depths, respectively.

319 Air temperatures in 2003/04 were also lower than in other years. Mean monthly air

320 temperatures for September 2001 to August 2005 are presented in Table 2. The winter

321 months from December to April were all colder during 2003/04 than during other years;

322 February and March, in particular, were over $8{ }^{\circ} \mathrm{C}$ colder. Monthly mean soil

323 temperatures were colder by 5 to $11^{\circ} \mathrm{C}$ for most of the winter of $2003 / 04$ than the

324 previous winter. The mean monthly temperatures during freeze-up were also warmest

325 in 2003/03. While the effect of a change in air temperature on soil temperatures under

326 variable snow covers is not straightforward, Stieglitz et al. (2003) demonstrated the

327 equivalent importance of air temperature and snow cover variability in determining

328 ground temperatures. It seems reasonable that air temperature and snow cover suffice to

329 explain differences in freezing rates between years. Since freezing rates in 2001/02,

330 2003/04 and 2004/05 are similar in magnitude, freezing in 2002/03 appears to have

331 been anomalously slow for this location.

332 Despite microclimatic changes from year to year, freeze-back within the frost boil is

333 generally rapid compared to other tundra locations, especially those protected with an

334 organic mat (e.g. Hinzman et al. 1998). Mean monthly winter air temperatures for each

335 of the years 2001/02, 2002/03 and 2004/05 fall within a few degrees of each other.

336 Thus, based on soil temperatures during 2002/03, the effect of an intermediate snow 
cover, under normal winter conditions, is to delay freeze-back by at least one month at most depths. The combined effects of the exposed frost boil mineral soil, shallow snow depth and cold winter temperatures in 2003/04 contribute to the extremely cold soil

340 temperatures in the frost boil.

\section{Thaw and Subsidence}

342 For the springs of 2003, 2004 and 2005, interpolated thaw depth data are shown in

343 Figure 5, along with air temperature, the timing of phase change at each TDR sensor 344 and the position of the ground surface. The ground surface and interpolated thaw depth 345 positions are shown, the former relative to its pre-thaw position. In all three years, the 346 correlation coefficient between the Stefan solution and the observed phase change was 347 better than $r=0.99$, with coefficients $\{A, B\}$ in equation 3 of $\left\{-3.67 \times 10^{-2}, 0.87 \times 10^{-2}\right\}$, $\left\{-2.98 \times 10^{-2},-4.59 \times 10^{-2}\right\}$ and $\left\{-3.09 \times 10^{-2},-7.27 \times 10^{-2}\right\}$ for 2003, 2004 and 2005, respectively. During the springs of 2004 and 2005, the profile thawed down to $0.12 \mathrm{~m}$ by May 15th. In 2003, however, thaw reaches this depth more than 2 weeks later, a reflection of differences in degree-days of thawing, which by July 18 totalled $687^{\circ} \mathrm{C} \cdot \mathrm{d}$ in 2004 but only $458{ }^{\circ} \mathrm{C} \cdot \mathrm{d}$ in 2003 , with thaw depths of 0.88 and $0.78 \mathrm{~m}$, respectively

353 (Figure 5). The spring subsidence in each year was similar in magnitude and reached $2.09 \times 10^{-2}, 2.24 \times 10^{-2}$ and $4.17 \times 10^{-2}$ m by July 18 in 2003, 2004 and 2005, respectively (for 458, 687, 527 degree-days of thawing). Nonetheless, the amount of subsidence occurring over the first $30 \mathrm{~cm}$ of thaw represented 68,19 and $44 \%$ of the end of summer total subsidence in 2003, 2004 and 2005, respectively, suggesting significant differences in the distribution of segregated ice from year to year, at least for the upper soil horizons. Egginton (1979) recorded subsidence of two mud boils west of Hudson Bay, and found that over $80 \%$ of total summer subsidence (6 to $9 \mathrm{~cm}$ ) occurred 
361 within the first month after thawing began when the active layer was about $40 \mathrm{~cm}$ deep,

362 in agreement with MacKay and MacKay’s (1976) observed ice lensing distribution in

363 non-sorted circles and with MacKay’s (1980) model of formation for non-sorted circles.

364 Time series of surface position measured with both heave rods and ultrasonic distance

365 sensors between the fall 2001 and spring 2005 show annual subsidence. As a group, the

366 surface position measurements show a steady decrease in surface elevation (Figure 6).

367 Ground surface position relative to the heave rods lowered from $5.1 \mathrm{~cm} / \mathrm{yr}$ at a point

$3682.47 \mathrm{~m}$ from the frost boil center to $7.5 \mathrm{~cm} / \mathrm{yr}$ at the frost boil center. Subsidence and/or

369 frost-jacking of the rods would result in lowering of the ground surface. In addition,

370 soil pit excavation and refilling at the end of the summer of 2001 was probably followed

371 by settling of the ground, leading to higher measured lowering.

372 Results from an undisturbed frost boil corroborate the observed subsidence. The

373 ultrasonic distance sensors were mounted on permafrost anchors sheathed in PVC

374 tubing to prevent frost-jacking, and the frost boil was not excavated. Using ground

375 surface positions at the end of summer from these sensors, mean subsidence is 5.1

$376 \mathrm{~cm} / \mathrm{yr}$ at the frost boil, and ranges from 2.0 to $4.8 \mathrm{~cm} / \mathrm{yr}$ for the other sensors for the

377 period from fall 2003 to fall 2005. The subsidence observed here affects both the frost

378 boil and the surrounding tundra, and does not directly affect active layer depth. Since

379 winter heave is similar from year to year and mostly due to the segregation of ice in the

380 upper $30 \mathrm{~cm}$ of the soil profile, the subsidence observed is attributable to the melting of

381 ice at the base of the active layer. It is more pronounced beneath the frost boil, where

382 summer thaw reaches greater depths, than beneath the surrounding tundra. We

383 observed $0.77 \mathrm{~m}$ of ice-rich soil (estimated $>90 \%$ by volume) beneath the active layer. 
384 The potential exists for continued subsidence and the northward expansion of Galbraith

385 Lake through thermokarsting.

\section{Heave}

387 Figure 7 shows three net winter heave profiles, measured between the end of summer

388 (late August - early September) and early spring (mid-May), superimposed on the

389 microtopography of the frost boil. Net winter heave increases towards a point just

390 outside the boil's edge from close to zero at a distance of $1.6 \mathrm{~m}$. The maximum heave of

391 around $0.12 \mathrm{~m}$ occurs outside the frost boil boundary in all three years. The unvegetated

392 frost boil heaves between 0.04 to $0.08 \mathrm{~m}$. The three heave profiles are remarkably

393 similar, given the differences observed in freezing rates for each fall season.

394 Usually, a few days after the ground begins to freeze from the surface downward, soil

395 temperatures between the upper and lower frost fronts reach slightly negative

396 temperatures (Osterkamp and Romanovsky 1997). In the high snow year, however, this

397 process is extended over a longer time period. Nonetheless, the depth of the freezing

398 front as a function of lateral position is similar from year to year (Figure 7). The $0{ }^{\circ} \mathrm{C}$

399 isotherms, recorded at 9:00 am on the indicated dates, all show a thicker frozen layer

400 beneath the frost boil $(10-30 \mathrm{~cm})$ than beneath the tundra $(10-15 \mathrm{~cm})$. Segregation of

401 ice at the frost front results in heave normal to the frost front. The freezing front beneath

402 the margin of the frost boil is inclined so that a normal vector to the freezing front will

403 have a lateral component pointing towards the center of the boil.

404 We explain the location of maximum net winter heave outside the frost boil in one of

405 two ways: either (i) the shape of the freezing front and the relative freezing rates

406 beneath the boil and its margin lead to greater heave at the frost boil's margin than at its

407 center, or (ii) maximum heave does occur at the frost boil center at some time during the 
winter but subsequent subsidence beneath the frost boil occurs prior to the end of snow melt (during the winter). A single winter measurement of frost heave made in November 2002 was 0.02 m higher than in the following pre-thaw May, suggesting that

411 sublimation or evaporation processes from the bare soil of the boil's apex could have

412 decreased the ice content over the winter. The microtopography, surficial cracking and

413 heave of the boil would contribute to these processes. The frost boils at Galbraith are

414 elevated above the surrounding tundra and the high winds in the Atigun Valley can blow the snow off the frost boils alone. Under these conditions the surfaces of the boils are observed to be desiccated. When the snow pack is sufficient to cover the frost boils,

417 there is no indication of the location of the boils at the snow surface. The snow pack is

418 necessarily thinner above the frost boils than over the tundra, and moisture migration 419 into the snow pack is exacerbated at the boil by a steeper temperature gradient through the snow pack. Since the soil here is at or near saturation on freezing, there can be no indication for this process using volumetric liquid water content, since it is independent of total water content at cold temperatures. Since thaw begins with the infiltration of melt water, the soil is saturated before all of the ice disappears in spring. Such a loss of 424 ice to the atmosphere is consistent with the shape of the heave curves in Figure 7. The amount of heave depends on the freezing rate, and the dramatic difference in freezing rate between 2003 and the other years lead us to expect differences in heave.

427 For example, O’Neill and Miller (1985) simulated heave and observed an increase in ice 428 segregation with a decrease in freezing rate. To explain the similarity between years, we must either invoke processes that remove ice in late winter after a slow freeze-back, or the possibility that heave is only weakly dependent on the freezing rate. The correspondence between the rate of water flow to the freezing front and the driving 
gradient (temperature) should enhance heave, so that we find the latter option difficult

to accept. We examine differences between the years in ice content below.

434

435

436

437

438

439

440

441

442

443

444

445

446

447

448

449

450

451

452

453

454

455

\section{Ice content as a function of depth}

The timing of subsidence and the temperature profile during thawing are related to the distribution of ice content as a function of active layer depth. Figure 8 shows the total volumetric ice content as a function of depth based on cumulative settlement and thaw in the springs of 2003, 2004 and 2005. The years refer to the spring in which ice content was observed; in each case, most of this ice probably formed during fall freezeup in the previous year. Ice contents throughout the profile lay between 0.5 and 0.8 , with lower ice content in 2003 in the upper $0.4 \mathrm{~m}$ of the profile than in subsequent years. Ice content exceeded the porosity in 2004 and 2005 over this same interval, suggesting that more segregation occurred in the upper profile during freezing in 2003 and 2004 than during the fall of 2002 (corresponding to the graph for 2003). The integrated ice contents between 0.12 and $0.40 \mathrm{~m}$ (for which depths data are available in all three years) are 0.16 (2003), 0.19 (2004) and $0.19 \mathrm{~m}$ (2005). Heave is the same (+/- 2 $\mathrm{cm}$ ) each year, but subsidence varies as much as $7 \mathrm{~cm}$ from year to year, suggesting that ice lost in deep thaw years is not replaced by segregation during freezing. In all three years, freezing occurs via both the descent of a freezing front from the surface and an increase in the height of the frost table, although the latter process is much more pronounced in 2002/2003 (Figure 4). The last depth to freeze in 2003/2004 is $0.79 \mathrm{~m}$. Ice content is locally higher between 0.85 and $0.90 \mathrm{~m}$ in both years. The qualitative similarity between increases and decreases in ice content with depth suggest that the relative distribution of ice from year to year is stable, except for the upper portion of the active layer, which is subject to repeated diurnal freeze-thaw cycles 
during freezing (Overduin et al. 2003). The spikes in ice content below $0.75 \mathrm{~m}$ correspond with the segregated ice observed in the field during excavation. Based on its position, this ice is probably segregated during upward movement of the frost table during freeze-back. Based on position, the inter-annual variability in shallow active layer ice content is determined by snow pack and heat transfer conditions at the surface, which affect post-freeze redistribution of water, rather than freezing rate. Deeper ice content does not seem to be freezing-rate dependent, and is therefore less variable from year to year.

\section{Volumetric latent heat production}

465 Latent heat changes (positive or negative) for the temperature profile beneath the frost 466 boil for the 2002/03 and 2003/04 winter periods, when the entire profile is at or below $467-1.5^{\circ} \mathrm{C}$, are presented in Figure 9. Since the soil is at or close to saturation on freezing, 468 changes in latent heat during this period are probably the result of freezing and thawing 469 in the frozen soil rather than vapour transport processes. Although it is probable that 470 other heat releasing or consuming processes are at work, such as sublimation near the 471 ground surface or vapour transport, the scale is given in $\mathrm{W} \mathrm{m}^{-3}$ and also in the rate of 472 phase change of water $\left(\mathrm{kg} \mathrm{m}^{-3} \mathrm{~d}^{-1}\right)$, using $333 \mathrm{~kJ} \mathrm{~kg}^{-1}$ as the latent heat of phase change. 473 Lighter colours indicate the consumption of latent heat. Our goal is to identify depths 474 and times of ice formation or disappearance during the winter.

475 In both winters, latent heat release dominates the profile between 0.4 and $0.9 \mathrm{~m}$ from 476 freeze-up until the end of April. This stands in stark contrast to the observations of 477 Roth and Boike (2001) for a site on Spitsbergen, who showed strong heat consumption 478 at intermediate depths during the cold winter period. They regarded this heat 479 consumption as evidence for evaporation of water and its diffusion upwards out of the 
soil into the snow pack or atmosphere. Corroboration of this vapour diffusion using changes in soil water content was not possible, since soil liquid water content does not change appreciably as water is removed. Net changes in saturation over the winter are masked by the infiltration and refreezing of melt water prior to soil thawing in the spring, which results in near-saturation of the soil at thaw. In addition to the fact that their analysis included constant soil thermal properties, ice segregation in the Galbraith Lake frost boils presumably draws moisture laterally which continues to freeze wellafter freezing begins. The integrated net latent heat fluxes between Jan 1 and March 31 for the years 2002/03 and 2003/04 are 28.2 and 23.6 $\mathrm{MJ} \mathrm{m}^{-2}$, corresponding to water amounts of 85 and $71 \mathrm{~kg} \mathrm{~m}^{-3}$. These estimates account for the depth intervals of 0.31 to $1.1 \mathrm{~m}$. Given that the upper and lower portions of this interval tend to lower values, net latent heat consumption probably occurs in the overlying and underlying soil horizons. These estimates can therefore only be regarded as upper bounds on the amount of ice created for the whole profile. In the slow freeze-up year (2003/04) more latent heat is released in the intermediate depths 0.5 to $0.98 \mathrm{~m}$ than in the previous year. This is more than balanced out by latent heat consumed in the upper part of the profile, consistent with greater moisture losses through evaporation and sublimation there, so that less latent heat is produced in 2003/04 than in 2002/03. The consumption of latent heat that occurs in the lower part of the horizon is difficult to explain, but may be related to the transport of moisture upward in the profile in response to the temperature gradient and

500 suggests the steady loss of ice at depths where the soil composition is more than $90 \%$.

501 These losses are observable as subsidence and represent a decrease in total permafrost thickness, but will not be observable using active layer probing or by observing ice content profiles that do not extend through the ice-rich layers. 
504 Shallower depths are affected by higher amplitudes of latent heat values, with episodes

505 of heat consumption, probably as a result of ice sublimation from the surface. In both

506 years, latent heat consumption deepens towards spring, as the soil is warmed from

507 above. The influence of winter temperature fluctuations is seen throughout the profile,

508 but is muted in the warmer winter (2002/03) compared to the following cold winter.

509 The latent heat release at depths below 0.9 m suggests a steady decrease in ice content

510 of the soil throughout the winter, consistent with heave amounts lower than those

511 predicted by the latent heat release at intermediate depths, and perhaps consistent with

512 the observed annual subsidence.

513

\section{Conclusions}

515 As a result of changes in ice content during freezing, frost boils at Galbraith Lake in the

516 Brooks Range of Alaska heave during freezing. Freezing rates vary greatly

517 interannually, but heave remains similar from year to year, both in terms of magnitude

518 and distribution across the frost boil. Enough latent heat is released in intermediate

519 depths in the frost boil to account for winter heave. The low net winter heave levels at

520 the center of the frost boil are attributed to loss of moisture via evaporation or

521 sublimation through the exposed mineral soil of the frost boil during the winter. We

522 suggest that the winter removal of water from shallow soil horizons at the frost boil's

523 center results in low lateral displacement of soil, leading to extrusion of lower horizons

524 but to insignificant downward movement of soil material at the frost boil margins.

525 Settling of the ground surface and the development of the active layer together permit

526 estimation of the pre-thaw vertical distribution of ice in the active layer. Net annual

527 subsidence suggests that melting ice at the base of the active layer is not replaced by 
528 annual winter heave, which results from ice formation in the upper portion of the frost 529 boil.

530 On the basis of surface position measurements during heave and subsidence, soil state

531 and composition measurements, and latent heat flux calculations, we observe small

532 interannual variability in heave magnitude for a frost boil, despite large changes in

533 freezing rate, snow cover and air temperature. More latent heat is released within the

534 soil during the winter than is necessary to account for the observed heave. It is

535 compensated for by processes consuming latent heat in the near-surface soil and below

536 the active layer. 


\section{Acknowledgements}

538 Prof. Bernard Hallet and an anonymous reviewer greatly improved this manuscript with

539 their insightful critiques. We are grateful to Jens Ibendorf, Prof. John Kimble, Gary

540 Michaelson, Prof. Chien-Lu Ping, and Joerg Sommer for help in the field. Soil analyses

541 were performed by the Soil Survey Staff at the National Soil Survey Center, USDA.

542 Funding was provided by an Inland Northwest Research Alliance (INRA) fellowship

543 and the National Science Foundation's Office of Polar Programs (OPP-9814984)

544 through the Office of Polar Programs, Arctic System Science. The Potsdam Institute for

545 Climate Impact Research graciously provided an office for P. P. Overduin during a

546 portion of the writing. 


\section{References}

548

549

550

551

552

553

554

555

556

557

558

559

560

561

562

563

564

565

566

567

568

569

570

571

572

573

574

575

576

577

578

579

580

581

582

583

584

585

586

Bittelli B, Flury M, Gaylon SC. 2003. A thermodielectric analyzer to measure the freezing and moisture characteristic of porous media. Water Resources Research 39(2). doi:10.1029/2001wr000930.

Burn CR. 1998. The active layer: two contrasting definitions. Permafrost and Periglacial Processes 9: 411-416.

Egginton PA. 1979. Mudboil activity, central District of Keewatin. In: Current research, Part B: Geological Survey of Canada, Paper 79-1B; 349-356.

Fuchs M, Campbell GS, Papendick RI. 1978. An analysis of sensible and latent heat flow in a partially frozen unsaturated soil. Soil Science Society of America Journal 42(3): 379-385.

Harris C, Helfferich D. 2005. Who is BOB? Agroborealis 36(2): 29-32.

Heimovaara TJ, Focke AG, Bouten W, Verstraten JM. 1995. Assessing temporal variations in soil water composition with time domain reflectometry. Soil Science Society of America Journal 59: 689-698.

Hinzman LD, Goering DJ, Kane DL. 1998. A distributed thermal model for calculating soil temperature profiles and depth of thaw in permafrost regions. Journal of Geophysical Research 103(D22): 28975-28991.

MacKay JR, MacKay DK. 1976. Cryostatic pressure in nonsorted circles (mud hummocks), Inuvik, Northwest Territories. Canadian Journal of Earth Sciences, 13 : 889-897.

MacKay JR. 1979. An equilibrium model for hummocks (nonsorted circles), Garry Island, Northwest Territories. Current research, Part A : Geological Survey of Canada Paper 79-1A, pp. 165-167.

MacKay JR. 1980. The origin of hummocks, western Arctic coast, Canada. Canadian Journal of Earth Sciences, 17 : 996-1006.

O’Neill K, Miller RD. 1985. Exploration of a rigid ice model of frost heave. Water Resources Research 21: 281-296.

Osterkamp TE. 2003. A thermal history of permafrost in Alaska. In Proceedings of the 8th International Conference on Permafrost, Zurich, Phillips M, Springman SM, Arenson LU (eds). Balkema: Lisse, Netherlands; 863-868.

Osterkamp, TE, Romanovsky, VE, 1997, Freezing of the Active Layer on the Coastal Plain of the Alaskan Arctic, Permafrost and Periglacial Processes, 8:23-44.

Overduin PP, Ping C-L, Kane DL. 2003. Frost boils, soil ice content and apparent thermal diffusivity. In Proceedings of the 8th International Conference on Permafrost, Zurich, Phillips M, Springman SM, Arenson LU (eds). Balkema: Lisse, Netherlands; 869-874.

Overduin PP, Yoshikawa K, Kane DL, Harden J. 2005. Comparing electronic probes for volumetric water content of low-density feathermoss. Sensor Review 25(3): 215221. 
606

607

608

609

610

611

612

613

614

615

616

617

618

619

620

621

622

623

624

625

Overduin PP, Kane DL, Loon WKP van. 2006. Measuring thermal conductivity in freezing and thawing soil using the soil temperature response to heating. Cold Regions Science and Technology 45(1): 8-22. DOI: 10.1016/j.coldregions.2005.12.003.

Ping C-L, Michaelson GJ, Overduin PP, Stiles CA. 2003. Morphogenesis of frost boils in the Galbraith Lake area, Arctic Alaska. In Proceedings of the 8th International Conference on Permafrost, Zurich, Phillips M, Springman SM, Arenson LU (eds). Balkema: Lisse, Netherlands; 897-900.

Roth K, Schulin R, Fluehler H, Attinger W. 1990. Calibration of time domain reflectometry for water content measurement using a composite dielectric approach. Water Resources Research 26: 2267-2273.

Roth K, Boike J. 2001. Quantifying the thermal dynamics of a permafrost site near NyÅlesund, Svalbard. Water Resources Research 37(12): 2901-2914. DOI: 10.1029/ 2000WR000163.

Sokratov SA, Golubev VN, Barry RG. 2001. The influence of climate variations on the thermoinsulation effect of snow cover and on the temperature regime in the underlying soil (in Russian, with English summary). Kriosfera Zemli 2: 83-91.

Stieglitz M, Dery SJ, Romanovsky VE, Osterkamp TE. 2003. The role of snowcover in the warming of Arctic permafrost. Geophysical Research Letters 30(13): 17211726.

Taras B, Sturm M, Liston GE. 2002 Snow-Ground Interface Temperatures in the Kuparuk River Basin, Arctic Alaska: Measurements and Model. Journal of Hydrometeorology 3: 377-394.

Vliet-Lanoë van B. 1991. Differential frost heave, load casting and convection: converging mechanisms; a discussion of the origin of cryoturbations. Permafrost and Periglacial Processes 2: 123-139.

Walker DA, Epstein HE, Gould WA, Kelley AM, Kade AN, Knudson JA, Krantz WB, Michaelson GJ, Peterson RA, Ping C-L, Raynolds MK, Romanovsky VE, Shur Y. 2004. Frost-Boil Ecosystems: Complex Interactions between Landforms, Soils, Vegetation and Climate. Permafrost and Periglacial Processes 15: 171188. DOI: $10.1002 / p p p .487$.

Washburn AL. 1956. Classification of patterned ground and review of suggested origins. Geological Society of America Bulletin 67: 823-865.

Yershov ED. 1990. General Geocryology. Cambridge University Press: Cambridge; 580.

Zoltai SC, Tarnocai C. 1981. Some nonsorted patterned ground types in Northern Canada. Arctic and Alpine Research 13(2): 139-151.

Zhu D-M, Vilches OE, Dash JG, Sing B, Wettlaufer JS. 2000. Frost heave in argon. Physical Review Letters 85: 4908-4911. 
642

643

644

645

646

647

648

649

650

651

652

653

654

655

656

657

658

659

660

661

662

663

664

665

666

667

668

669

670

671

672

673

\section{List of Figures}

Figure 1. A normalized difference image (NDVI) of the study site using near-infrared and visible red wavelengths shows the distribution of periglacial landforms at the study site. NDVI is an index for reflection from photosynthesizing vegetation. It is used here to identify patches of ground free of vegetation, which appear black. A number of periglacial features are visible, including: A. ice, cored mounds; B. thermokarst features; C. frost boils; D. remnant polygonal ice wedges; E. dark spots within the oval are people. The collection of dark spots and square at upper right are people and equipment. With the exception of the frost boils (C), vegetation cover is complete. The field book in the upper left inset image is $12 \mathrm{~cm}$ wide (aerial image courtesy of Dr. N. Harris, University of Alaska Fairbanks).

Figure 2. A cross-section of the frost boil (dashed line) and surrounding (thick line) microtopography measured at $0.05 \mathrm{~m}$ intervals on August 27, 2001, with the positions of the buried instruments. Subsurface instruments include $0.3 \mathrm{~m}$ long TDR sensors for volumetric liquid water content, thermistors for soil temperature, heave rods and transient heat pulse sensors for thermal conductivity and diffusivity. Heave rods extended from anchors in the permafrost to above the ground surface.

Figure 3. Measured thermal conductivity $\left[\mathrm{W} \mathrm{m}^{-1} \mathrm{~K}^{-1}\right]$ at $0.2 \mathrm{~m}$ depth beneath the frost boil center as a function of soil temperature $\left[{ }^{\circ} \mathrm{C}\right]$ Three years of data are included in the parameterization, which applies to temperature less than or equal to $-1.5^{\circ} \mathrm{C}$ only. Around the freezing temperature, latent heat effects inflate the apparent thermal conductivity. In the unfrozen soil, the conductivity is sensitive to changes in soil water content.

Figure 4. Soil temperature (grey scale at right) and soil liquid water content (contour interval of $0.2 \mathrm{~m}^{3} \mathrm{~m}^{-3}$ for values from 0.1 to $0.5 \mathrm{~m}^{3} \mathrm{~m}^{-3}$ ) beneath the centre of the frost boil for four hydrologic years. The shallowest water content sensor was inoperative during freezing in 2001.

Figure 5. The cumulative degree-days of thawing (upper graph), the position of the ground surface and the frost table depth relative to the ground surface (at $0 \mathrm{~m}$, lower graph) are shown for the summers of 2003, 2004 and 2005. Surface position is measured over the frost boil center. Frost table depth is observed as the decrease in liquid water content during freezing and interpolated between sensor depths by fitting thaw depth to degree-days of thawing using the Stefan solution for thaw depth. Observed thaw depths (frost table) are shown as circles for both years. Fitting parameters are given in the text.

Figure 6. The end of summer position of the ground surface as measured using 5 buried heave rods (2001-2003) and 5 ultrasonic distance sensors (2003-2005). Each rod/sensor's data is shown relative to its September 14, 2003 position. There are 25 observations shown, incorporating 2 sensing techniques and 5 locations.

Figure 7. The frost boil topographic cross-section is superimposed on three thin solid lines indicating heave measured between the end of summer and the beginning of 
674 subsequent thaw for the winters of 2001/02, 2002/03 and 2003/04. The vertical scale for 675 the heave data has been exaggerated by a factor of two (scale at right). Frost front 676 penetration profiles recorded at 9:00 am on the dates shown are shown for four years.

677

678 Figure 8. Pre-thaw volumetric soil ice content estimated from spring subsidence rates 679 as a function of the depth of thaw, for 2002/2003, 2003/2004 and 2004/2005. Soil 680 porosity measured on profile soil samples is indicated as grey circles; porosity values 681 are joined with a grey dashed line as a visual aid.

682

683 Figure 9. The latent heat production calculated from the temperature data. A black line 684 and a discontinuity in the grey scale indicates the transition between heat source and 685 sink.

686 
Table 1. Selected frost boil soil profile properties.*

\begin{tabular}{|c|c|c|c|c|c|c|}
\hline $\begin{array}{l}\text { sample } \\
\text { depths }\end{array}$ & $\begin{array}{c}\begin{array}{c}\text { bulk } \\
\text { density }\end{array} \\
{\left[\mathrm{g} \mathrm{cm}^{-3}\right]}\end{array}$ & $\begin{array}{l}\text { clay, silt, sand } \\
\text { contents }\end{array}$ & $\begin{array}{c}\begin{array}{c}\text { total } \\
\text { carbon }\end{array} \\
{[\% \mathrm{wt}]}\end{array}$ & porosity & $\mathrm{C} / \mathrm{N}$ & $\begin{array}{c}\text { CEC } \\
{\left[\mathrm{meq}^{-} \mathrm{g}^{-}\right.} \\
\left.{ }_{1}\right]\end{array}$ \\
\hline 0.06 & 1.62 & $43.9,44.4,11.7$ & 2.21 & 0.44 & 10 & 0.121 \\
\hline 0.16 & 1.74 & $44.5,44.2,11.3$ & 2.21 & 0.40 & 9 & 0.139 \\
\hline 0.28 & 1.76 & 43.2, 43.7, 13.1 & 2.32 & 0.39 & 8 & 0.122 \\
\hline 0.44 & 1.75 & $43.4,43.1,13.5$ & 2.25 & 0.39 & 9 & 0.126 \\
\hline 0.66 & 1.73 & $43.2,45.1,11.7$ & 2.18 & 0.40 & 11 & 0.125 \\
\hline 0.83 & 1.75 & $36.0,38.7,25.3$ & 2.62 & 0.39 & 9 & 0.113 \\
\hline 1.09 & 1.72 & $44.3,43.3,12.4$ & 2.19 & 0.40 & 9 & 0.141 \\
\hline
\end{tabular}

from region surrounding boil:

0.10
(A-horizon)

n. d.

$12,34,54$

6.1

0.69

33

n. d.

0.20

0.5

$15,15,70$

4.0

0.88

0.129 NE., Thursday, February 17, 2005. 
691 Table 2. Mean monthly air temperatures for the four-year period of record.

\begin{tabular}{lrrrr}
\hline & $\mathbf{2 0 0 1 / 0 2}$ & $\mathbf{2 0 0 2 / 0 3}$ & $\mathbf{2 0 0 3 / 0 4}$ & $\mathbf{2 0 0 4 / 0 5}$ \\
\hline September & 2 & 2 & 0 & -1 \\
October & -3 & -1 & -3 & -3 \\
November & -7 & -5 & -6 & -6 \\
December & -12 & -7 & -17 & -14 \\
January & -13 & -16 & -22 & -14 \\
February & -16 & -17 & -26 & -16 \\
March & -14 & -16 & -24 & -15 \\
April & -13 & -12 & -16 & -15 \\
May & -1 & -5 & -2 & 2 \\
June & 6 & 7 & 11 & 8 \\
July & 8 & 8 & 10 & 7 \\
August & 4 & 6 & 9 & 8 \\
\hline
\end{tabular}

692 


\begin{tabular}{|c|c|c|}
\hline $\mathrm{A}$ & constant & -- \\
\hline B & constant & -- \\
\hline C & heat capacity ( $C_{n}$ : of the $n$th soil component) & $\mathrm{J} \mathrm{kg}^{-1} \mathrm{~K}^{-1}$ \\
\hline$D$ & thermal diffusivity & $\mathrm{m}^{2} \mathrm{~s}^{-1}$ \\
\hline$R_{T}$ & thermistor resistance & $\Omega$ \\
\hline$T$ & soil temperature & ${ }^{\circ} \mathrm{C}$ \\
\hline $\bar{T}$ & mean daily air temperature & ${ }^{\circ} \mathrm{C}$ \\
\hline$T_{f}$ & freezing temperature & ${ }^{\circ} \mathrm{C}$ \\
\hline$k$ & thermal conductivity & $\mathrm{W} \mathrm{m^{-1 } \mathrm { K } ^ { - 1 }}$ \\
\hline$r_{h}$ & heat production (+ve) or consumption (-ve) in the soil & $\mathrm{W} \mathrm{m}^{-3}$ \\
\hline$t$ & time & $\mathrm{s}$ \\
\hline$z$ & depth below ground surface & $\mathrm{m}$ \\
\hline$\Delta z_{0}$ & change in ground surface position relative to permafrost & $\overline{\mathrm{m}}$ \\
\hline$\Delta z_{f t}$ & change in frost table position relative to permafrost & $\mathrm{m}$ \\
\hline$\delta \mathrm{x}$ & uncertainty in $\mathrm{x}$ & units of $x$ \\
\hline$\theta$ & volumetric content & $\mathrm{m}^{3} \mathrm{~m}^{-3}$ \\
\hline$\theta_{i}^{\prime \prime}$ & volumetric segregated ice content & $\mathrm{m}^{3} \mathrm{~m}^{-3}$ \\
\hline$\rho$ & density & $\mathrm{kg} \mathrm{m}^{-3}$ \\
\hline$\eta$ & soil porosity & -- \\
\hline \multicolumn{3}{|c|}{ Subscripts } \\
\hline$a$ & air & \\
\hline$i$ & ice & \\
\hline$j, k$ & measurement depth, time & \\
\hline$n$ & $n$th soil component & \\
\hline$w$ & water & \\
\hline$s$ & soil & \\
\hline
\end{tabular}


695

696
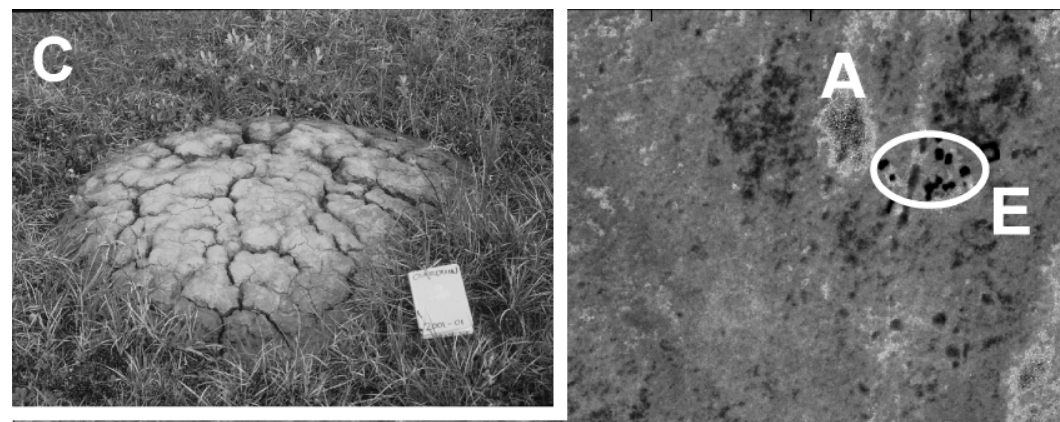

B

B
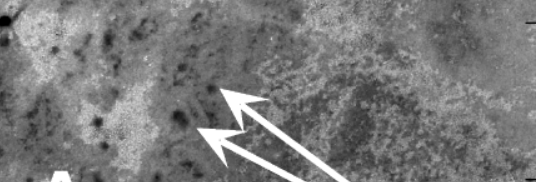

A
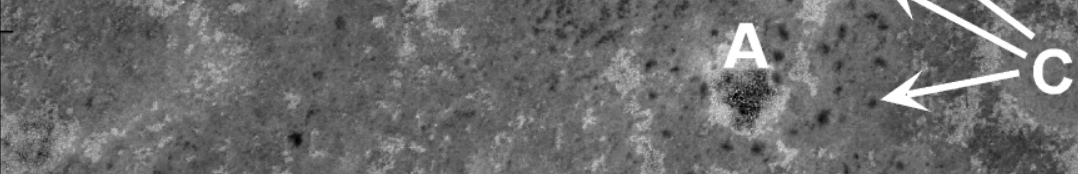

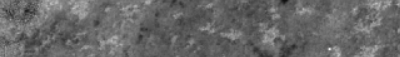

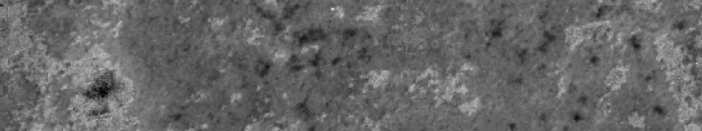

9

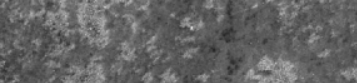

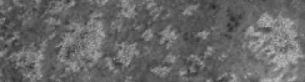
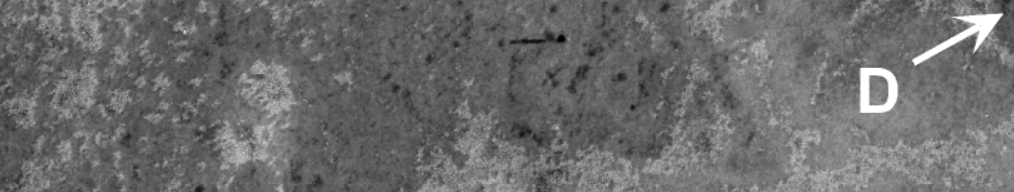

D)

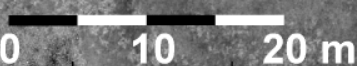

697 


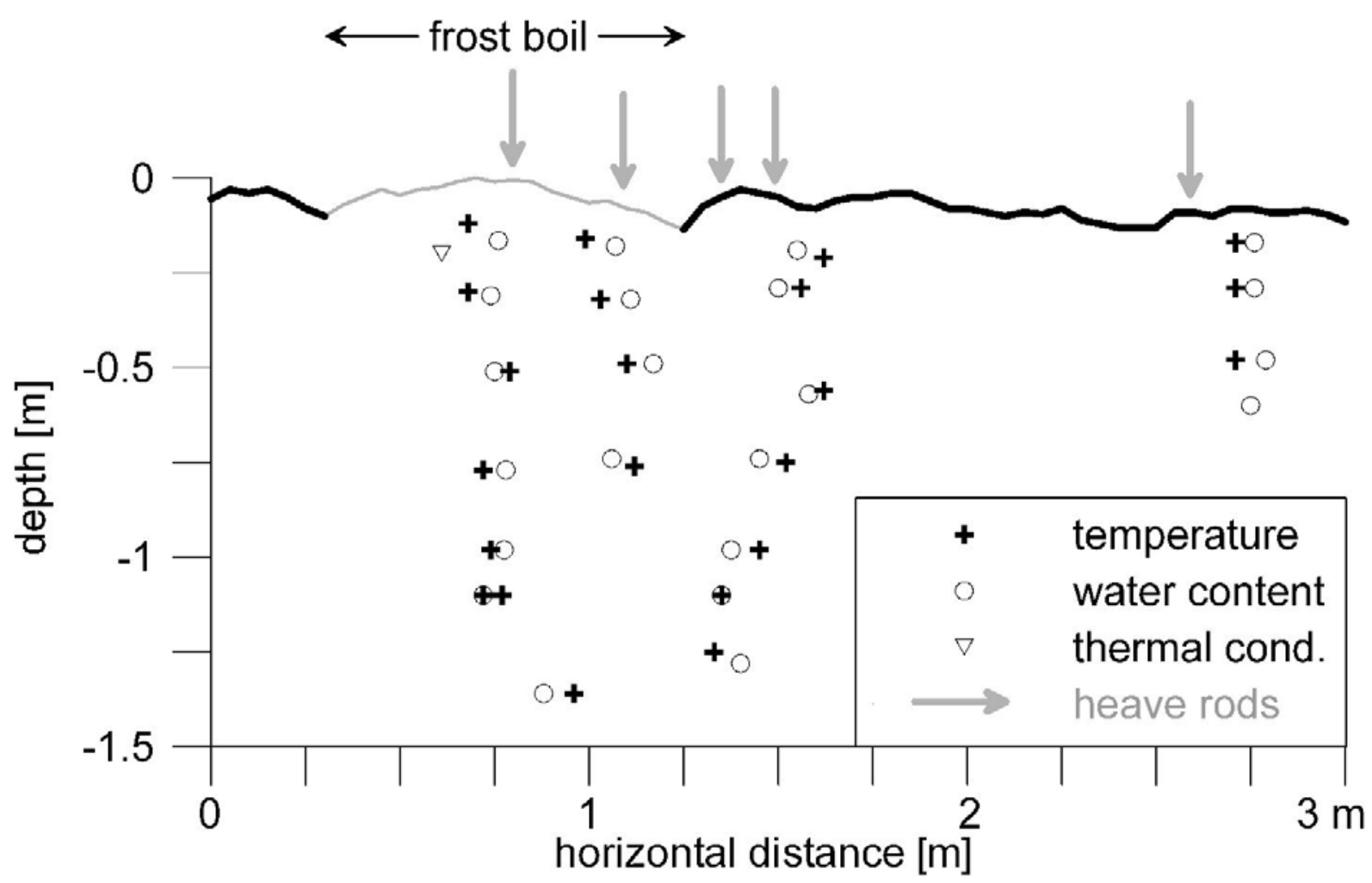

698 
700

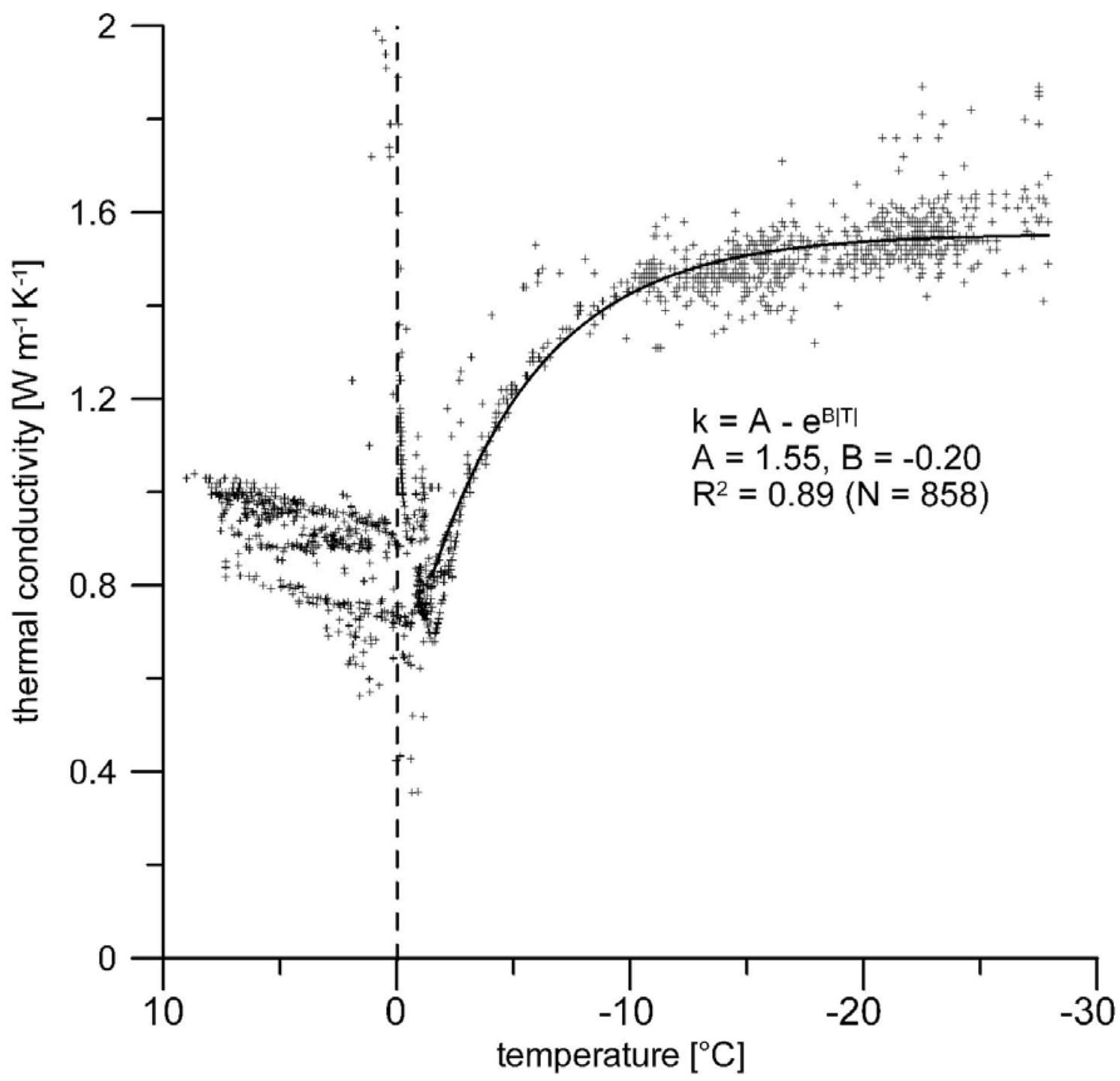





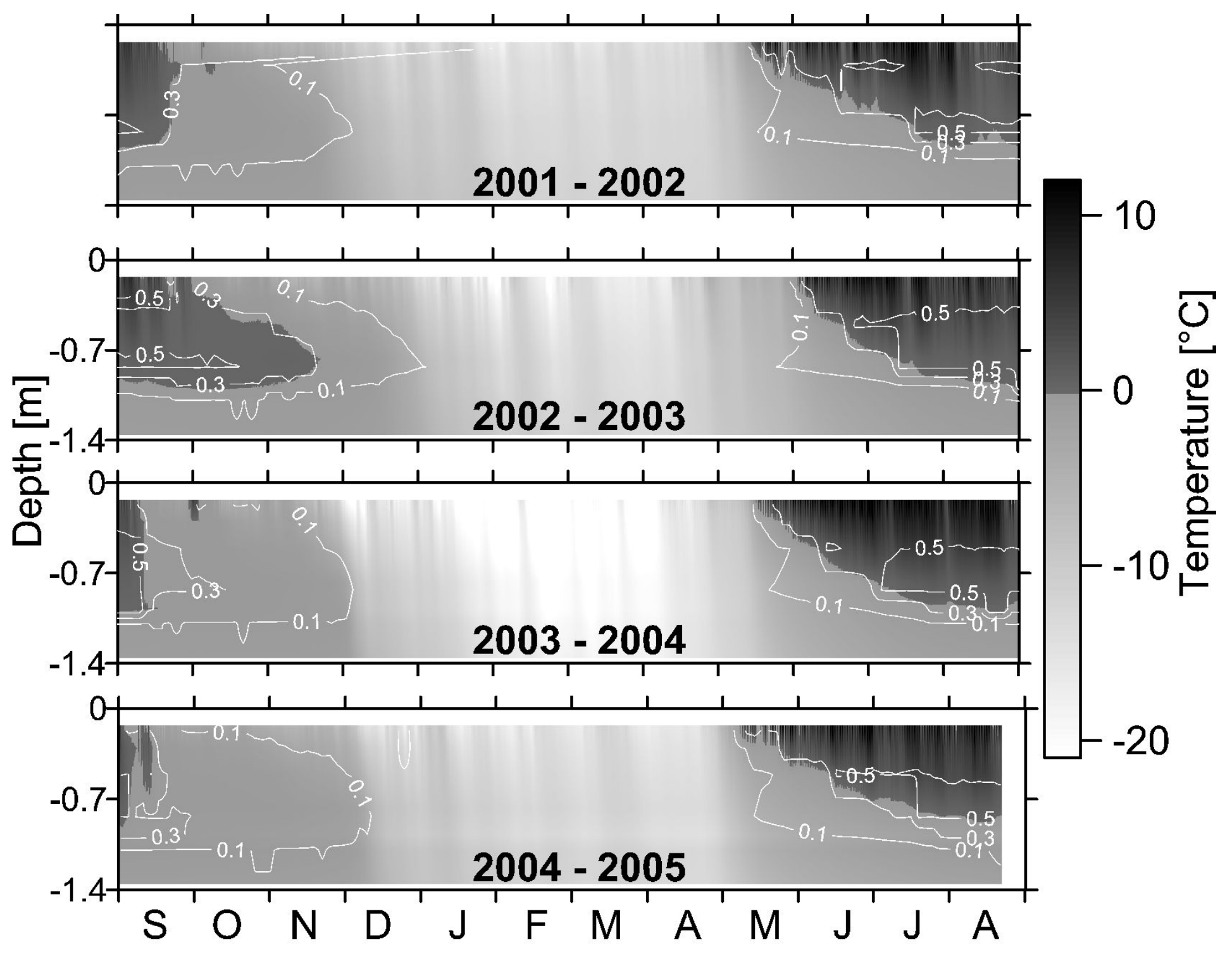




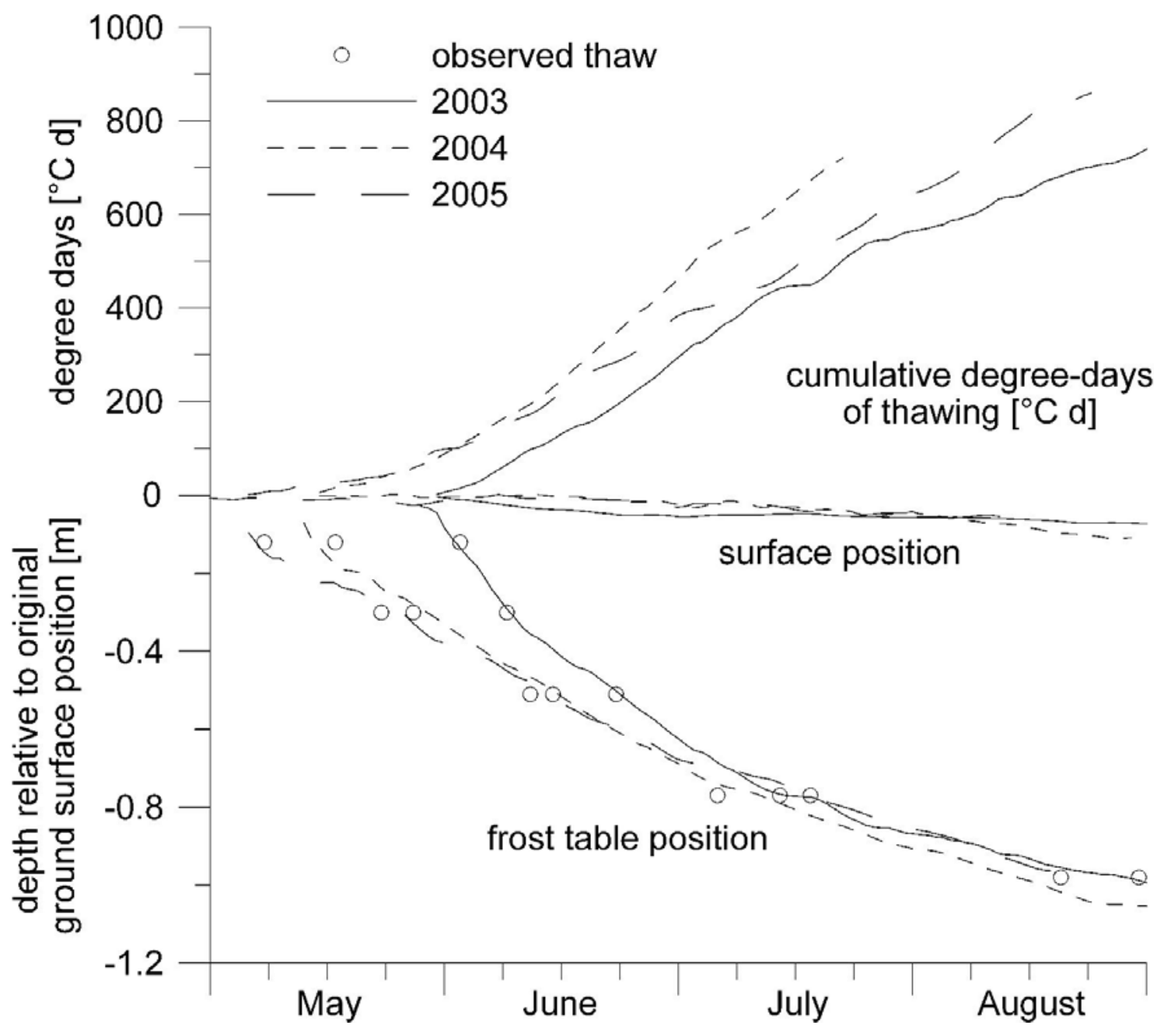

703 


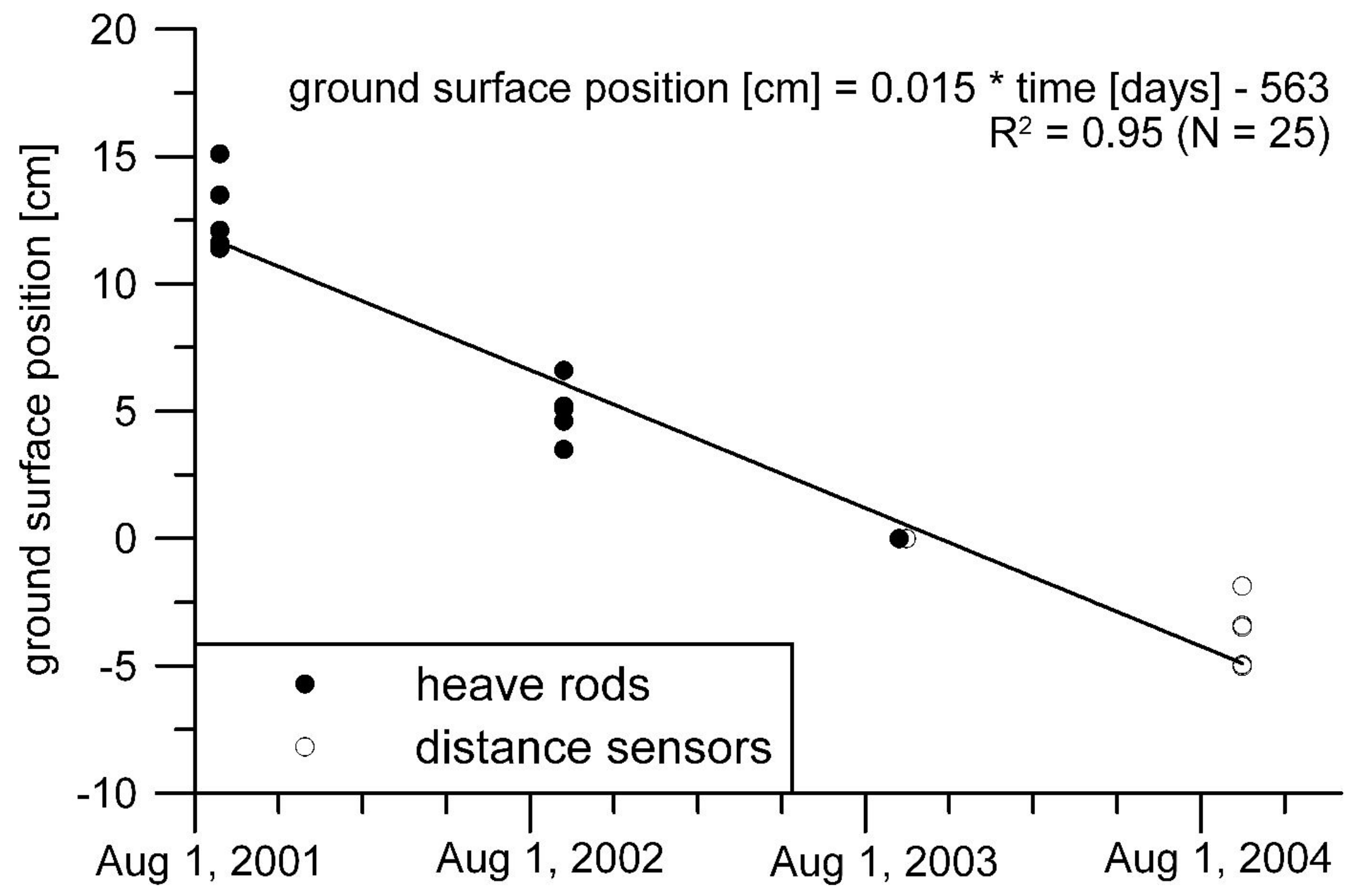




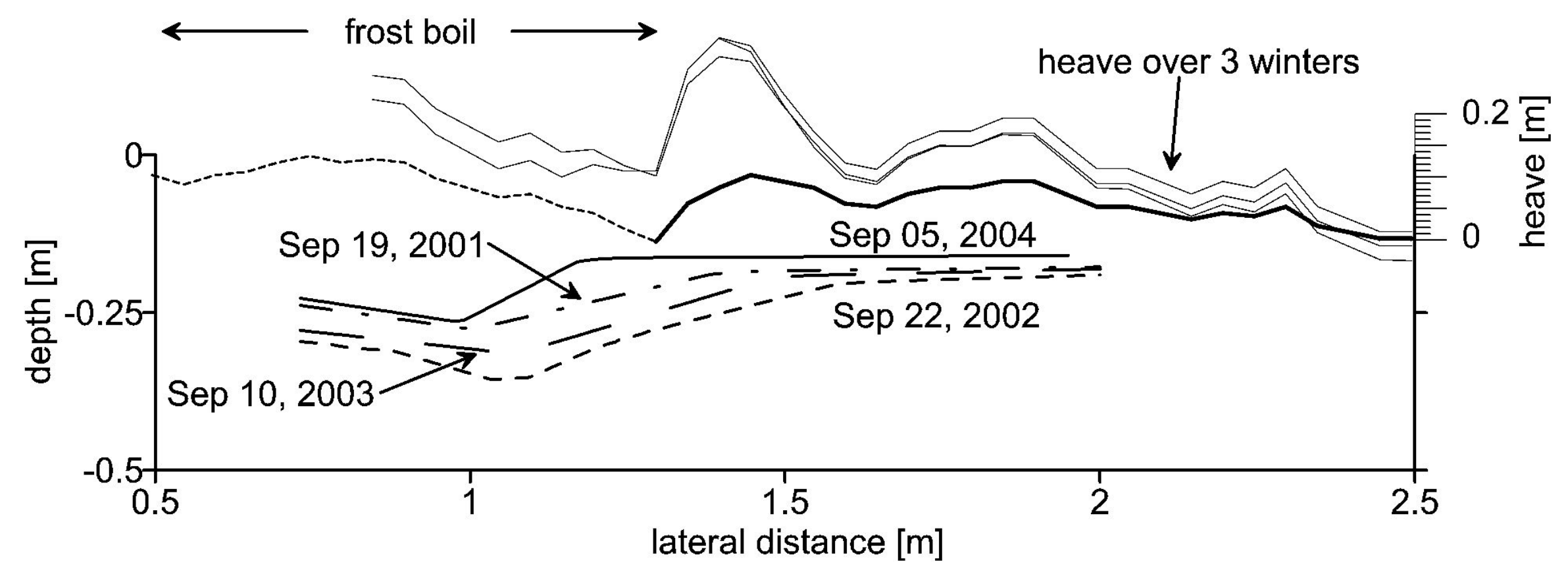




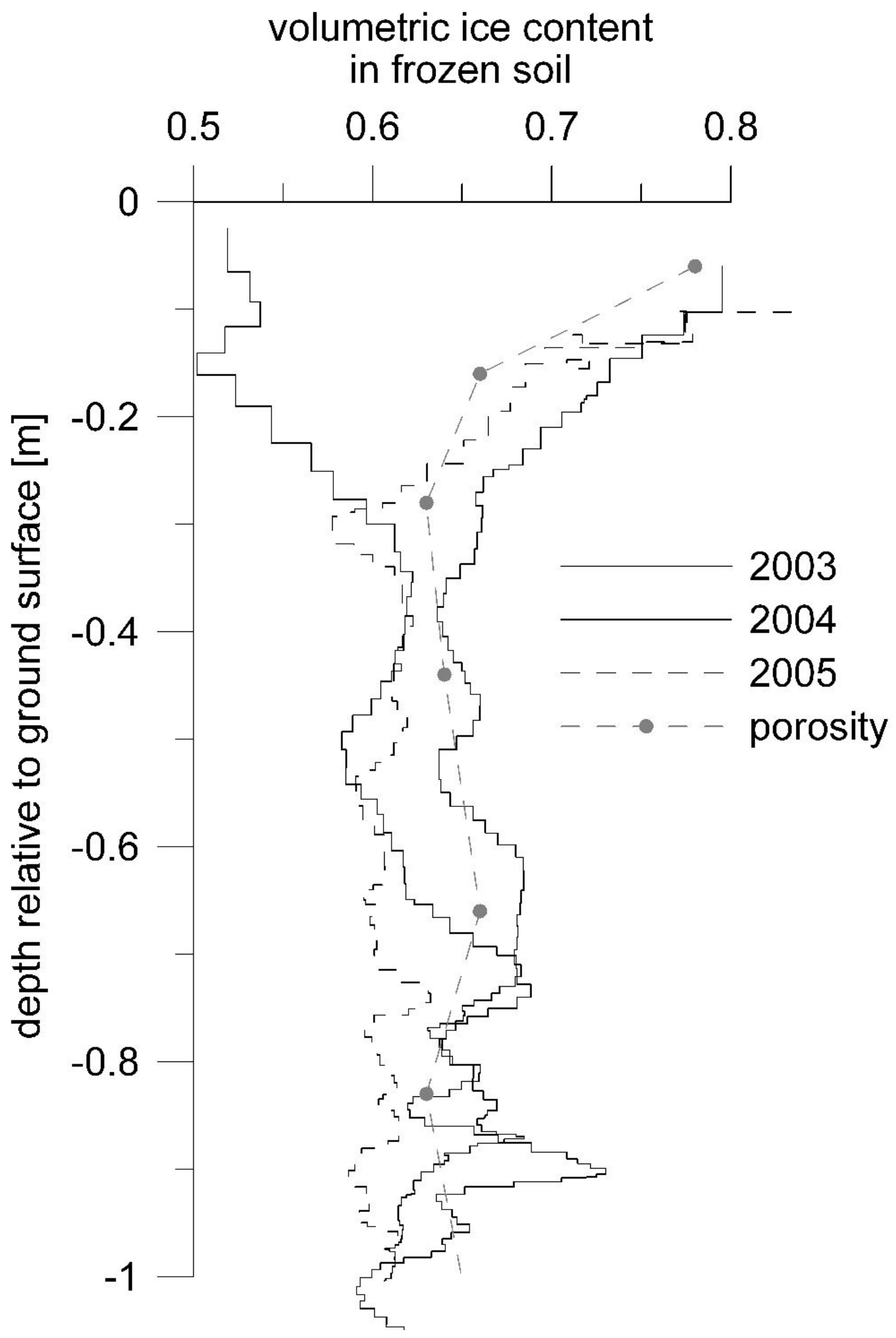




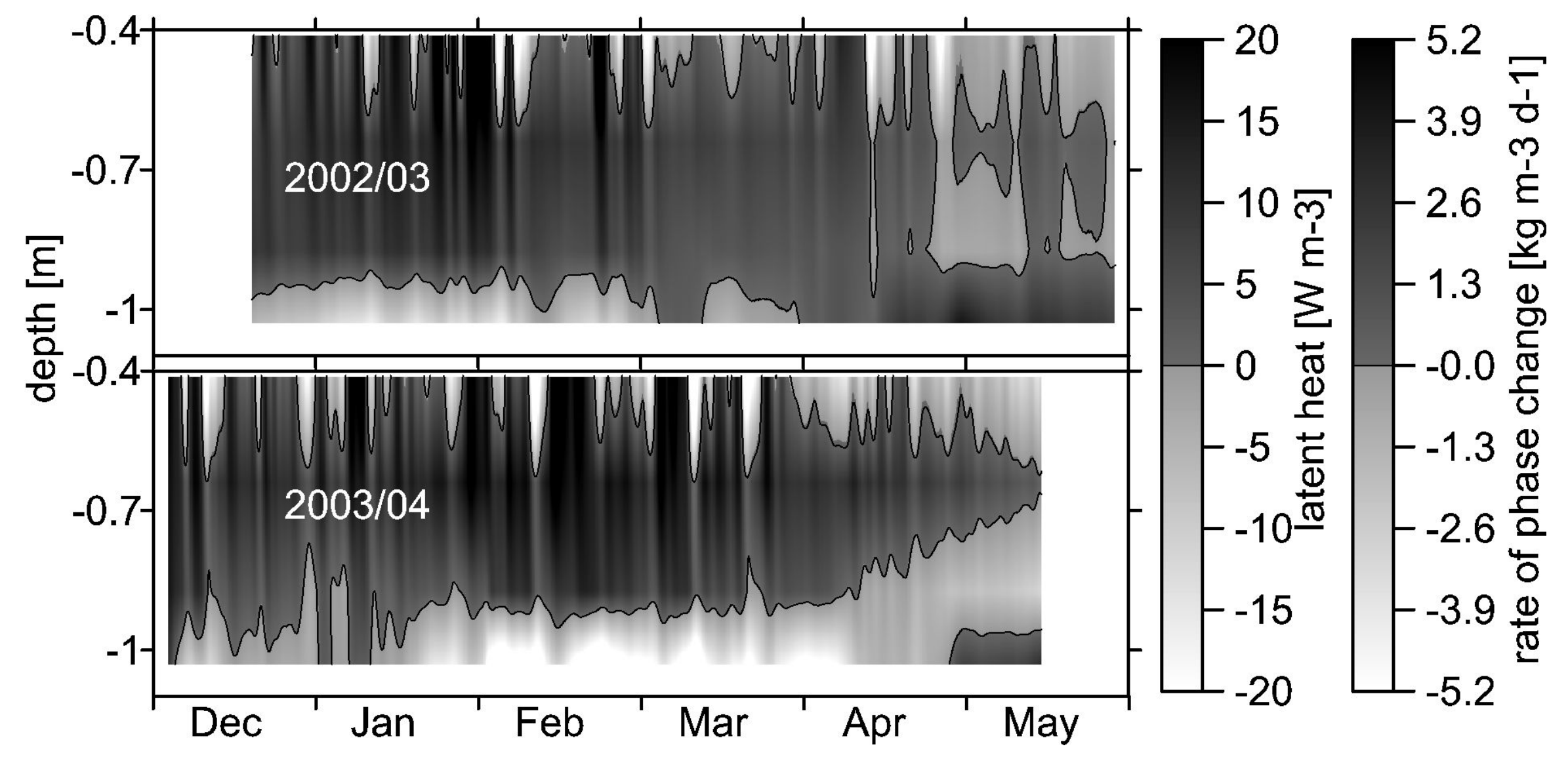

